\title{
Analysis of the Effect of Olfactory, Approach Behavior, and Experiential Marketing toward Purchase Intention
}

\author{
Cherish Anggie \\ Pelita Harapan University \\ Jony Oktavian Haryanto \\ Satya Wacana Christian University
}

\begin{abstract}
The drive of retail business competition is getting tighter and causing retailers to seek to entice consumers to be regular and faithful at their stores. Retailers need to understand consumer behavior in order to obtain what is desired by consumers. Therefore, consumer behavior needs to be studied considering various factors which can influence consumer decisions to buy a product. The emergence of BreadTalk in Indonesia in the bakery industry with a different concept bakery store has caused rapid development in this industry. One strategy used by BreadTalk to encourage consumers to visit, feel the different experience, and ultimately to increase consumer purchase intention is to use dimensional olfactory as one of the elements in the store ambience. With this phenomenon, this study aims to find the significant influence of the olfactory, approach behavior, experiential marketing toward purchase intention. Collecting data in this study was done by spreading questionnaires to students of the University of Pelita Harapan, who had visited and shopped at BreadTalk Supermal Karawaci. The questionnaires were distributed to 150 respondents. The variables that exist in the study are measured using the Likert scale. The sample collection technique used was a non-probability sampling technique of sampling with a purposive sampling method. The data are then processed by using reliability analysis, validity, and methods of structural equation modelling analysis. From the results of this study the significant influence from olfactory to 3 variables mentioned above can be seen.
\end{abstract}

Abstrak: Persaingan di dalam dunia bisnis yang semakin ketat mengharuskan peritel untuk menjaga pelanggannya supaya senantiasa datang dan nyaman di toko mereka. Peritel harus mampu memahami perilaku konsumen untuk mengetahui apa yang mereka inginkan. Oleh karenanya, perlu untuk mempelajari faktor-faktor yang mempengaruhi keputusan pembelian konsumen. Salah satu toko roti yang sukses adalah Breadtalk yang menampilkan konsep berbeda. Salah satu strategi yang diterapkan oleh Breadtalk untuk menarik pelanggan, menawarkan pengalaman yang berbeda dan akhirnya meningkatkan intensi pembelian konsumen adalah dengan menggunakan olfactory. Melihat fenomena tersebut, penelitian ini bertujuan untuk mengetahui pengaruh olfactory, approach behavior, dan experiential marketing terhadap intensi

Corresponding authors. E-mail: jonyharyanto@yahoo.com

ISSN: $1141-1128$

http://www.gamaijb.mmugm.ac.id/ 
pembelian. Penelitian ini mengambil data dengan menyebarkan kuesioner kepada 150 mahasiswa Universitas Pelita Harapan yang mengunjungi dan berbelanja di BreadTalk Supermal Karawaci. Variabel-variabel yang ada dalam penelitian ini diukur dengan skala Likert dengan metode purposive sampling. Data kemudian dicek validitas dan reliabilitasnya kemudian dianalisa dengan structural equation modelling. Dari hasil analisis ditemukan bahwa olfactory berpengaruh signifikan terhadap variabel-variabel yang telah disebutkan diatas.

Keywords: consumer innovativeness; fashion; online shopping intention; purchase experience; shopping orientations 


\section{Introduction}

Despite thinking about increasing profit, retail stores now should be thinking of how to attract more customers. Nowadays shopping is a pleasure and has its own emotion which customers feel and enjoy in the store (Schifferstein and Blok 2002). Therefore, the role of the atmosphere in a store is important in the retail business as a contributing factor in creating a more attractive and comfortable store ambience. Using scent in a store builds a uniqueness of the store itself which can remind customers of the store itself (Mitchell et al. 1995). In this study, the authors will discuss one of the store ambience elements of olfactory dimension as it is related to the presence of scent in a store environment. Researchers conclude that the presence of a pleasant scent is an inexpensive and effective way to enhance consumers' perceptions and reactions to the service environment (Chebat and Michon 2003; Spangenberg et al. 1996).

BreadTalk as one of the retail stores engaged in bakery business is the first store which uses smells as a point of attraction for consumers. Researchers contend that "smell is the sense that is most closely linked to the brain's emotional center, and could therefore be harnessed to provoke a powerful emotional reaction" (Spence 2002: 19). The use of the olfactory dimension in a store gives a different experience than other stores; as the consumer realizes that the smell gives a distinct impression to consumers. This may bring a positive impact for retailers that will lead to increased corporate profits in accordance with their intended target and may provide satisfaction for customers when they visit the store.
BreadTalk comes with a new bakery concept which is likely more a boutique which sells many types of bread; they also display the bread products in open display, which customers can see directly. Then, they create an open-kitchen concept where the customers can see the process of making bread directly. This is a phenomenon in the bakery business that can be found at many bakery stores. According to Sullivan and Adcock (2002), stimuli from a store (pictures, sounds, smells, etc.) are perceived by customers, processed by a unique way and processed individually. The first level of response to stimulation is the development of an emotional state described by two variables, namely pleasure and arousal. The second level is the behavioral response to stimuli based on the emotional state of the buyer. This behavior can be either approach or avoidance behavior. Approach behaviors include willingness to move toward the environment, participate more broadly, and the increasing tendency to buy. Avoidance behavior is the opposite, with a view moving from the environment, reducing participation, and a decreased tendency to buy.

It can be concluded that BreadTalk use the smells of fresh bread as a marketing strategy. The new concept of a bakery store also becomes a different experience for the customers. Therefore, BreadTalk is the first bakery store which combines the store ambience with shopping experience which is different from the other stores. Despite the importance of store environment, it is unbelievable that research to identify the influence of olfactory toward experiential marketing which finally leads to purchase intention is scarce (e.g. Halloway 1999; Bone and Jantrania 1992). Therefore, this study investigates the effect 
of using the store ambience element of olfactory, the approach behavior from the customer, and the experiential marketing the customer felt on purchase intention at BreadTalk Supermal Karawaci.

In the next section, the author presents a conceptual framework of this study. We then review literature relevant to the relationships among the constructs. Next, we describe the research methodology and reporting the findings. After that, we discuss implication of the findings and directions for future research.

\section{Conceptual Framework and Hypotheses Development}

The conceptual model underlying our research is exhibited in Figure 1 showing whether olfactory, approach behavior and experiential marketing gives significant influence to purchase intention. Then, author will also analyze whether the experiential marketing gives significant influence to approach behavior.

\section{Olfactory}

Lindstrom (2005) explained that an olfactory dimension is associated with the presence of scent in a store environment. Three main factors in this dimension are the attractiveness of the aroma, the scent of arousal or the ability to cause a response, and the intensity of the strength of the aroma. The relationship between aromas and pleasure mentioned gives effect on the nervous system of the brain (Sullivan and Adcock 2002).

According to Lindstrom (2005), the olfactory system can identify various types of smells surrounding us every day. Odors evoke an impression, sensation, memory, and associations. The smell can also affect us more strongly than what is initially imaginable. Pleasant aroma has been found to increase awareness and performance in recalling a pleasant memory, increase pro-social behavior, and increased time spent in the store.

Aroma can also increase the level of purchase by the shopper (Baron and Bronfen 1994; Mitchell et al. 1995). Effects of aroma can be explained partly by the concept of conformity or harmony, or by the level the aroma of a given product acceptable to match with the existing environment (Bone and Jantrania 1992). Research also shows the conformity or harmony of flavor; if the intensity of the aroma can be detected, the possibility of shoppers using the route around

Figure 1. Conceptual Model

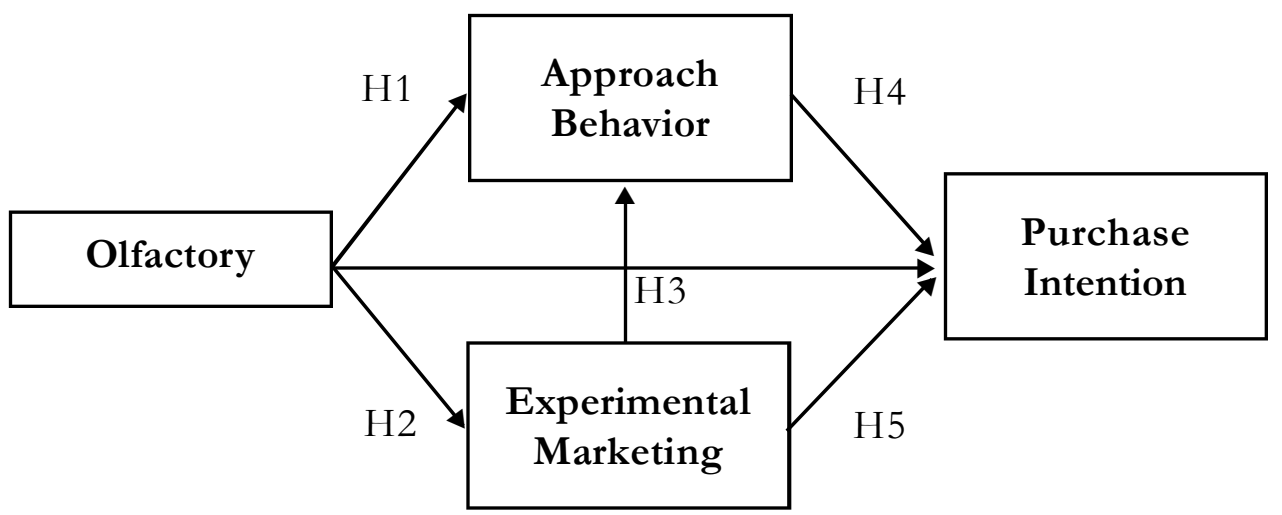


to make purchases and spend more time processing the data with a wide range of factors, improving the evaluation. Using a smell that is not appropriate reduces the possibility of making purchases, using only the main routes to persuade buying and spending and little time to process with a narrower range of factors (Mitchell et al. 1995; Spangenberg et al. 1996). From the explanation above, we conclude to our first hypothesis as follows:

\section{H1: Olfactory has a positive effect on approach be-} havior.

Mehrabian and Russell (1974) argued that environmental psychology withdraw from the paradigm of stimulus-organism-response (SOR), where the environment is a stimulus (S) which contains instructions for combining the internal evaluation $(\mathrm{O})$ to influence the society, which then created the approach-avoidance response (R). The two behaviors that have been described above prove that the role of scent on consumer behavior is positive. Sense of smell has the highest emotional connection, higher than other senses because the human olfactory system in the brain senses scent and sends a fast signal to the limbic system and connects emotions to memory (Soars 2009). Spangenberg et al. (1996) found that the use of scent in a store can give good influence consumers to visit the store longer and then provide a positive influence on consumer behavior where consumers spend more time on a pleasant scent when used. Based on this explanation, in more formal words, we say:

H2: Olfactory has a positive effect on experiential marketing.

\section{Approach Behavior}

Environmental stimuli in a store will affect consumer behavior. The result of these influences can be an approach or an avoid- ance behavior by the consumer. Mehrabian and Russel (1974), quoted by Sullivan and Adcock (2002) explains that the approach behavior has characteristics such as the desire to remain physically in the environment, participate more actively, and increase customer's purchase intention. The avoidance behavior has characteristics, such as the desire to move away from the environment, less participation, and the tendency to buy less.

According to Sullivan and Adcock (2002), there are four types of approach and avoidance behavior associated with retail stores: the physical approach and avoidance that is associated with the main purpose of the subscription store, the exploratory approach and avoidance which is associated with a search at the store, the communication approach and avoidance which is associated with interaction between vendors and employees of the store sales. Finally, there is the performance and satisfaction approach and avoidance, which is associated with shopping frequencies and additional time and expense in the store.

With the concept of the approachavoidance response, a person participating and approaching the environmental stimuli that provides a pleasant affective response and avoids stimuli that give an unpleasant affective response. However, the author focuses on the approach response where the response is positive in consumer behavior, in which they are happy to spend time in the store and are also willing to pay more for the products they like. This positive approach response was chosen because this positive approach could be used by companies to apply an appropriate marketing strategy. For instance, by understanding that a specific ambience could stimulate customers, than companies could apply that ambience in their retail environments. 


\section{Experiential Marketing}

Schmitt (1999) defines the word "experience" as an experience of personal events that occur due to certain stimuli (such as those provided by marketers before and after the purchase of goods or services). Pine II and Gilmore (1999) argue that the experience is an event that happened and binding on each individual personally. While the notion of marketing according to Berman and Evans (2004) is an activity to anticipate, manage and achieve customer satisfaction through the exchange process. Based on the above definition, experiential marketing can be called a marketing strategy undertaken by the retailer, not only based on products offered to customers, but also the experience gained by customers at the time they are in the shop and when purchasing the product. In experiential marketing, customers are able to differentiate one product or service from another since they experience themselves directly in the process of selecting and consuming the product or service using five approaches: sense, feel, think, act and relate (Andreani 2007).

The main focus of an experiential marketing is in response to senses, influences, actions, and relationships. Therefore, retailers should be able to create different experiences to enable the creation of a separate memory for consumers. There are several benefits in the view of Schmitt (1999), among others: (a) to revive a brand that is deteriorating, (b) to differentiate one product from competitor products, (c) to create the image and identity of a retail company, (d) to promote innovation, (e) to persuade the trial, purchase, and customer loyalty.

Today, the olfactory as one of dimensional elements in the store ambience has begun to be used at stores that sell nonfood or services. Spa is one of the retail stores that uses smell as a trigger in the way of marketing. The presence of a pleasant scent to evoke the memory stored in the brain that causes the memory of the aroma as more emotional than the other stimuli (Halloway 1999).

According to Schmitt (1999), one of the concepts and models of experiential marketing is strategic experiential modules, where marketing activities are seen as holistic (comprehensive) experiences: sense, feeling, cognitive, physical and lifestyle (act), and the relationship with the culture or a specific reference (relate) to give the imagination of the product. From the five stages described above, sense can be associated with this hypothesis in which the sense that consumers gain through his/her experience when he/she sees or tries the product, such as sound, smell, touch/taste, the shape of the product. Thus, the scent is also part of the experience that consumers feel where they are invited to experience something different from a retail store that focuses on aromas specifically created as a stimulus for the consumer. From this we formulate our third hypothesis:

\section{H3: Experiential marketing has a positive effect on approach behavior.}

\section{Purchase Intention}

Assael (1998) explained that purchase intention is a behavior that emerges in response to an object. Purchase intention is also a repeat request indicating the desire of customers to make purchases again. Consumers tend to make purchases of an item if the customer has obtained the expected level of satisfaction.

Meanwhile, according Simamora (2002), interest is something that is personal and relates to individuals who have an interested attitude toward an object and have the 
strength and encouragement to conduct a series of behavior to approach or obtain a certain object. Kotler (2003) also argued that there are two factors that affect a person's buying interest in the decision making process, namely an unexpected situation and respect to others.

Experiential marketing is an effort by retailers to create a pleasant experience with the consumer, so that they tend to favor a particular brand (Kertajaya 2003). Based on the above definition, experiential marketing is done as a marketing strategy for retailers to create a different experience for customers by using scent as an element in the ambience of a neighborhood store. Andreani (2007) explained that from the perspective of the consumer, they are able to differentiate one product or service from another since they experience themselves directly in the process of selecting and consuming the product or service using five approaches, sense, feel, think, act and relate.

Experience in shopping today is not only in the form of promotions or offers that appeal to consumers, but from the use of scent as well, which can provide a different experience. A pleasant aroma that is created in a store will always be remembered by the customers, and the memory will work to create the emotion of a different and unique experience Times Bookstore has used this strategy with air freshener that is very typical so that customers can feel it in each of their outlets. In effect, consumers feel comfortable to spend time in bookstores because the smell was created to make people feel comfortable and it feels like home when they are inside of the stores. It can be concluded that smell provokes positive behavior from consumers; a pleasant aroma makes its own experience for consumers so they are always reminded of the store when they smell the aroma, which generates intention to revisit the store. In more formal words, we say:

\section{H4: Approach behavior has a positive effect on purchase intention.}

Two-dimensions (pleasure and arousal) of Mehrabian and Russels' emotional experience paradigm Pleasure-Arousal-Dominance (PAD) will influence the stimuli from a store and consumer response to product and environment. According to Sullivan and Adcock (2002), stimuli from a store (pictures, sounds, smells, etc.) are perceived by customers, processed in a unique way and processed individually. The first level of response to stimulation is the development of an emotional state described by two variables, namely pleasure and arousal. The second level is the behavioral response to stimuli based on the emotional state of the buyer. This behavior can be either approach or avoidance behavior. Approach behaviors include willingness to move toward the environment, participate more broadly, and the increasing tendency to buy. Avoidance behavior is the opposite, with an intention to move away from the environment, reduce participation, and decreased tendency to buy.

Assael (1998) explained that the purchase intention is a behavior that emerged in response to the object. Purchase intention is also a repurchase which shows customer's intention to do the repurchase. Consumers tend to make purchases of an item if the customer has obtained the expected level of satisfaction. When consumers feel satisfied with the services rendered or products purchased, it encourages the intention to remake a purchase to meet the needs of the consumers want. Therefore, the emotional dimension in approach behavior, namely pleasure and arousal acts as bridge to the purchase intention. Based on this explanation, we conclude: 
H5: Experiential marketing has a positive effect on purchase intention.

Bilson (2001) suggests that the trend offers an approach which optimizes more of the five senses, emotions, and affection. In the end, the ability to provide the dimensions or the imagination of the products and services becomes an unforgettable experience that can influence customers to enjoy the product. Customers are not only buying products, but also there is experience and emotions that are created. Moreover, an attractive product display is one part of the experience in shopping, when customers feel happy with the things seen visually. Halloway (1999) found that if a costumer likes the environment of the retailer than it will lead him/ her to make a purchase. This is related to consumers' desire to buy a product where they pleased at the moment, because they want to feel a pleasant experience again, or they want to share experiences that are already being felt to the people closest. In more formal words, we say:

\section{H6: Olfactory has a positive effect on purchase in- tention.}

Scent can lure a person to visit and eventually purchase a product in the store. Aroma can be used toward consumers so that they feel they do not want to go, it can cause emotional feelings, and to make purchases (Soars 2009). Knasko (1989) and Lipman (1990) found that the aroma is created in an ambience to extend the time for the customers to remain in the store. When a person feels happy or satisfied in buying goods or a service, the feeling will strengthen the buying interest, but if they are not satisfied it will eliminate the interest.

Another opinion, expressed by Belk (1975) is that many factors affect the shop- ping desire of customers, i.e., non-situational factors and situational factors. Situational factors are all factors specific to the time and place of observation which does not follow from knowledge of personal attributes and stimulus. The effect of this can be demonstrated systematically by the current behavior. One example of the physical surroundings refers to the location, decor, scent, sound, lighting, temperature, and merchandise or other material around the object stimulus. Meanwhile, non-situational factors also are common characteristics of an individual or an object, for example: personality, sex, race from one individual, and brand image, quality, size, and function of an object that can be purchased.

The main purpose of this study is to investigate the effect of olfactory dimension, approach behavior and experiential marketing on purchase intention. On the basis of literature, we hypothesize the relationships among olfactory, approach behavior, and experiential marketing with purchase intention. The relational paths among the constructs are summarized in Figure 1.

\section{Methodology}

\section{Pretest Study}

For the pretest, survey data were collected from a convenience sampling of 30 respondents in Jakarta. Measures were captured relative to the services of the bakery shop "BreadTalk" at Lippo Karawaci Mall, Tangerang, Indonesia. The aim of this pretest was to examine the scales that would be used to test the model. Results from the pretest showed that the reliability of all scales was adequate given Nunnally's (1978) standard. Some questions, which appeared to be 
problematic based on the pretest respondents' comments, were reworded for the main study.

\section{Scale Development}

On the basis of items used in literature and the definitions established in our research, we generated a pool of sample measures. All items were measured on 5-point Likert-type scales, with anchors of $1=$ strongly disagree and $5=$ strongly agree. For our main study, there are 150 respondents taken using convenience sampling involved in this research.

\section{Measurement reliability and Validity}

In order to test the validity, the research was conducted by using common factor analysis. According Simamora (2004), factor analysis carried out in conditions between the one factor and another factor has similarity, continuity, and overlap. These conditions can be identified by correlating a factor with other factors. If the correlation is low, it can be said that the items contained in each of these factors are measured with different variables, and vice versa. Analysis of factor scores can be seen from Kaiser-Meyer-Olkin (KMO) and Measures of Sampling Adequacy (MSA). If the scores of KMO and MSA greater than 0.5 means that factor analysis proper or appropriate for use, and can be further processed (Malhotra 2007). In other words, the items have a strong relationship if the KMO and MSA scores above 0.5 . The test of validity in this study is using SPSS version 18. As a result, 19 items were retained for five constructs: 4 for olfactory, 5 for approach behavior, 5 for experiential marketing, and 5 for purchase intention. The items selected are reported in Table 1.

Table 1. Operational Measures and Scale Reliability Values

\begin{tabular}{lll}
\hline Item & KMO & MSA \\
\hline Olfactory $(\mathrm{a}=0.900)$ & 0.802 \\
When I enter BreadTalk, I feel: & \\
OF1 The presence of smell makes me confortable & 0.869 \\
OF2 $\quad$ The presence of the smell makes me feel at home in the store & 0.827 \\
$\quad$ BreadTalk & 0.788 \\
OF3 $\quad$ The presence of the smell makes me calm in the store BreadTalk & 0.752 \\
OF4 $\quad$ The presence of the smell makes me happy to be in the store & \\
$\quad$ BreadTalk & 0.853 \\
Approach Behavior (=0.881) & \\
When I enter BreadTalk, I feel: & 0.866 \\
AB1 The smell of bread makes me want to continue to visit BreadTalk & 0.814 \\
AB2 $\quad$ The smell of bread makes me want to buy bread BreadTalk & 0.856 \\
AB3 $\quad$ The smell of bread catch my attention & 0.896 \\
AB4 $\quad$ The smell of bread makes me buy more BreadTalk & 0.855 \\
AB5 $\quad$ The smell of bread makes me want to keep buying bread BreadTalk & \\
&
\end{tabular}




\section{Continued from Table 1}

\begin{tabular}{lll}
\hline Item & KMO & MSA \\
\hline Experiential Marketing (a = 0.884) & 0.767 & \\
When I enter BreadTalk, I feel: & \\
EM1 Impressed with the service & 0.768 \\
EM2 Get something different than the other & 0.735 \\
EM3 Impressed with the display products & 0.814 \\
EM4 Impressed with the cleanliness & 0.741 \\
EM5 Impressed with store atmosphere with the open-kitchen concept & 0.773 \\
Purchase Intention (a = 0.879) & \\
PI1 I plan to visit BreadTalk this month & 0.848 \\
PI2 I hope that I can always buy bread at BreadTalk & 0.865 \\
PI3 I want to buy BreadTalk if there is any chance & 0.820 \\
PI4 If I go to the mall, I always not forget to buy bread at BreadTalk & & 0.830 \\
PI5 I will recommend BreadTalk to my friends & 0.901 \\
\hline
\end{tabular}

Tabel 2. Construct, Hypotheses, $\beta$ Coefficient, Findings $(\mathbf{n}=150)$

\begin{tabular}{cccc}
\hline Constructs/Paths & Hypotheses/(expected sign) & $\boldsymbol{\beta}$ coefficient & Findings \\
\hline $\mathrm{OF} \rightarrow \mathrm{AB}$ & $\mathrm{H} 1(+)$ & 0,519 & Supported \\
$\mathrm{OF} \rightarrow \mathrm{EM}$ & $\mathrm{H} 2(+)$ & 0,299 & Supported \\
$\mathrm{EM} \rightarrow \mathrm{AB}$ & $\mathrm{H} 3(+)$ & 0,367 & Supported \\
$\mathrm{AB} \rightarrow \mathrm{PI}$ & $\mathrm{H} 4(+)$ & 0,260 & Supported \\
$\mathrm{EM} \rightarrow \mathrm{PI}$ & $\mathrm{H} 5(+)$ & 0,238 & Supported \\
$\mathrm{OF} \rightarrow \mathrm{PI}$ & $\mathrm{H} 6(+)$ & 0,185 & Supported \\
\hline
\end{tabular}

Test of reliability in this research is using Cronbach Alpha as a reliability coefficient for each constructs. The higher value of coefficient alpha $(0<$ coefficient alpha $<1)$ is the more consistent or higher level of reliability. When it reached .60, it reached the cutoff level of reliability recommended for theory testing research (Malhotra 2007). Test of reliability in this study is using SPSS version 18. As a result, all constructs were reliable. Table 2 explains the validity of the constructs used in this research. 


\section{Sample and Procedure}

After a pretest $(\mathrm{n}=30)$ to assess and purify the measures, we conducted a main survey to test the hypotheses, using data obtained from students in the University of Pelita Harapan who had shopped in BreadTalk. The total number of respondents was 150 people. The gender of the respondents were 44 percent men and 56 percent women; the age of respondents is 2.67 percent ages below 18 years old, 54 percent ages $19-21$ years old, 28 percent ages $22-25$ years old, and 15.33 percent above 26 years old; the status of respondents is 11.33 percent married and 88.67 percent single; the last education of respondents is 15.33 percent undergraduate, 68 percent graduate, 26.67 percent postgraduate; the expense in a month is 30 percent lower than Rp2 million, 35.33 percent Rp2 - 3.5 million, 21.33 percent Rp3.5 - 4 million, 13.33 percent above Rp5 million; occupation is 2.67 percent entrepreneur, 23.33 percent private employee, 84.67 percent student; frequency of visits per month is 1.33 percent less than twice, 36.67 percent third-forth times, 12.67 percent more than five times; people who accompany respondents in doing the purchase is 32 per- cent alone, 44 percent friend, 34 percent family, 1.33 percent girl/boy friend; length becoming customer is 10.67 percent less than 1 year, 52 percent $1-3$ years, 37.33 percent above 3 years; BreadTalk as the first choice is 45.33 percent agree, 54.67 percent disagree; respondents who have visited BreadTalk this month is 53.33 percent have, 46.67 percent have not.

\section{Testing the structural model}

The model component in Figure 1 connecting the endogenous and exogenous variables is called the structural model. The assessment of the overall fit of the proposed model, which ensures that it is an adequate representation of the entire set of causal relationships, is shown in Table 3.

Based on the results, it can be concluded that the proposed model explaining the role of olfactory in building approach behavior, experiential marketing and purchase intention is statistically reasonable.

\section{Results}

Exploratory and confirmatory analyses were conducted. First, exploratory principal

Table 3. Goodness of Fit Indexes

\begin{tabular}{cccc}
\hline Goodness of Fit Indexes & Cut off value & Analyses Value & Model Evaluation \\
\hline Chi Square & $\begin{array}{r}\mathrm{P}=5 \% \text { Degree of } \\
\text { Freedom }=390\end{array}$ & 444.325 & The smaller the better \\
Probability & $=0.05$ & 0.030 & Not Good Fit \\
AGFI & $=0.90$ & 0.869 & Marginal Fit \\
GFI & $=0.90$ & 0.890 & Marginal Fit \\
NFI & $=0.95$ & 0.976 & Good Fit \\
CFI & $=0.95$ & 0.979 & Good Fit \\
RMSEA & $=0.08$ & 0.025 & Good Fit \\
\hline
\end{tabular}


Table 4. Structural Equation Model

\section{Equation}

1 Approach $=0.32 *$ Experien $+0.60 *$ Olfactor, Errorvar. $=0.3, \mathrm{R}^{2}=0.65$
(0.092)
(0.086)
(0.073)
3.54
6.93
4.85

2 Experien $=0.48 *$ Olfactor, Errorvar $=0.77, \mathrm{R}^{2}=0.23$
$(0.11)$
4.24
$(0.25)$
3.07

3 Intentio $=0.31 *$ Approach $+0.22 *$ Experien $+0.21 *$ Olfactor, Errorvar. $=0.59, \mathrm{R}^{2}=0.41$
(0.15)
$(0.11)$
2.10
2.03
$(0.12)$
1.65
$(0.11)$
5.17

Table 5. Result of Structural Model Relationship

\begin{tabular}{clll}
\hline Hyphotesis & Hypothesis Statement t-value Supported / Not & & \\
\hline H1 & Olfactory has a positive effect on approach behavior & 6.93 & Supported \\
H2 & Olfactory has a positive effect on experiential marketing & 4.24 & Supported \\
H3 & Experiential marketing has a positive effect on approach behavior & 3.54 & Supported \\
H4 & Approach behavior has a positive effect on purchase intention & 2.10 & Supported \\
H5 & Experiential marketing has a positive effect on purchase intention. & 2.03 & Supported \\
H6 & Olfactory has a positive effect on purchase intention & 1.98 & Supported \\
\hline
\end{tabular}

component analysis (varimax rotation) and reliability analyses were performed to refine the scales. For all constructs, a one-dimensional structure was found.

A confirmatory factor analysis (CFA), using LISREL 8.80 with maximum-likelihood (ML) estimation (Joreskog and Sorbom 1993), was then performed on the scales. To assess the model, multiple fit indexes are reported. Standardized data were used for all subsequent analyses. The process of standardization eliminated the bias introduced by the difference in the scales of the several attributes or variables used in the analysis" (Hair et al. 1995: 435). Overall model fit indexes indicated that the CFA model was consistent with the data, with all fit indexes equal to, or better than, recommended values.

\section{Discussions}

\section{The Positive Influence of Olfactory Toward Approach Behavior}

The results of this study support previous research which was done by Spangenberg et al. (1996) found that the use of scent in a store can influence consumers to visit the store longer and then provide a positive influence on consumer behavior where consumers spend more time when a pleasant scent is used. It has been found that pleasant aroma can increase awareness and performance in recalling a pleasant memory, increase pro-social behavior, and increase time spent in the store. Aroma can also increase the level of purchase by the shopper (Baron and Bronfen 1994; Mitchell et al. 1995). 


\section{The Positive Influence of Olfactory Toward Experiential Marketing}

The results of this study is supported by a theory which is presented by Schmitt (1999): one of the concepts and models of experiential marketing is strategic experiential modules where marketing activities are seen as a holistic approach to (comprehensive) experiences: sense, feel, cognitive, physical and lifestyle (act), and the relationship with the culture or a specific reference (relate) to give the imagination of the product. From the five stages described above, sense can be associated with this hypothesis through the sense that consumers gained through their experience when they saw or even tried the product, such as sound, smell, touch/taste, the shape of the product. Thus, scent is part of the experience that consumers can feel when they are invited to experience different experiences from retail stores that focus on aromas specifically created as a stimulus for the consumer.

\section{The Positive Influence of Experiential Marketing toward Approach Behavior}

The results of this study are supported by a theory which is presented by Kertajaya et al. (2003) that experiential marketing is an effort by retailers to create a pleasant experience with the consumer so they tend to favor a particular brand. Experience in shopping today is not only in the form of promotions or offers that appeal to consumers, but the use of scent can provide a different experience. Moreover, the concept of experiential marketing can be an alternative for retailers because basically this concept emphasizes that it is important for any business to continue to create and enhance customer experience before, during, and after the pur- chase occurs. The trick is to touch the emotional side of customers deeper, not just on the purely rational level.

\section{The Positive Influence of Approach Behavior toward Purchase Intention}

This hypothesis is supported by a theory from Mehrabian and Russell (1974), quoted by Sullivan and Adcock (2002): stimuli from the store in the form of images, sounds, smells, and others were arrested by the shopper and processed in a unique way according to the individual shopper. There are emotional states that formed the pleasure of the circumstances in which shoppers feel comfortable in the store, and arousal is a state where consumers feel happy or excited. With a happy feeling or emotion that is built up, consumer buying behavior is also increasing.

Other contributing factors to consumer behavior are customer satisfaction and recommendation of the preferred bakery products for other people who also participated in the perceived experience. It is tailored to the theory of Assael (1998) who explained that the purchase intention is a behavior that emerges in response to the object. Purchase intention is also a repurchase which shows customer's intention to do the repurchase. Consumers tend to make purchases on an item if the consumer has obtained the expected level of satisfaction.

\section{The Positive Influence of Experiential Marketing toward Purchase Intention}

As noted by Pine II and Gilmore (1998) it is essential in the creation of experiential marketing to create a valuable experience for consumers. Viewing the BreadTalk unique store concept with the concept of resemblance to a boutique, bakery products and then arranged with neat and attractive with a 
sense of the diverse variants, as well as a unique form of bread, the things make consumers a unique shopping experience and fun. Bilson (2001) suggests that the trend should offer a better approach to optimize the five senses, emotions, and affection and in the end be able to provide the dimensions or the imagination of the products and services, which become unforgettable experiences that can influence consumers to enjoy the product. Consumers are not just buying products, but there is an experience and emotions are created.

\section{The Positive Influence of Olfactory Toward Purchase Intention}

This hypothesis uses the theory of Simamora (2004) which stated that a large stimulus often produces a larger purchase intention, such as: a loud voice, striking color, and aroma that stings. The smell that stings has been conducted by BreadTalk, which is deliberately making the open-kitchen concept so the aroma of bread freshly cooked can be smelled by the customers. When a pleasant aroma has been found that can increase awareness and performance in a fun memory recall, increase pro-social behavior, and increased time to spend in the store. Aroma increases the level of purchase by the shopper (Baron and Bronfen 1994; Mitchell et al. 1995).

\section{Conclusions and Implications}

Based on the above findings, we came to conclusion that in order to create a purchase intention, the retailers should develop approach behavior and experiential marketing through olfactory first. The application of an appropriate retail environment (i.e. olfactory) will create an experiential marketing and approach behavior which finally leads to purchase intention. Hence, it is necessary for retailers to conduct research about customers' needs and wants for their preferences in the ambience of the retailers. Once they find it, it will give benefits for the retailers as well as give an unforgettable experience to customers. This experience will lead to approach or positive behavior and finally push customer purchase intention.

\section{Limitations and Future Research}

This study has limitations because the research was done only at BreadTalk Supermal Karawaci, and it is a bakery store, so the results can only represent a small fraction of consumers, of which the respondents were mostly students from University Pelita Harapan. Future studies may use other different research sites and different types of respondents in order to get better results.

In this study, we use medium to large retailers. Further research can separate the study of medium retailers and large retailers. Thus more specific points of view of medium retailers and large retailers can be obtained by marketing efforts undertaken by company and their relationship with their assessment of brand equity.

There are many variables not examined in this study in relation to the impact on purchase intention. Other variables that could be further investigated in future research are: store layout, service and product quality, different objects of research, i.e. nonfood stores.

Another limitation from this study is 
that we only tested the approach behavior from Mehrabian and Russel (1974) whereas avoidance behavior was not tested for this study. Future research could accommodate these two approaches in order to make it more comprehensive.

\section{References}

Assael, H. 1998. Consumer Behavior and Marketing Action. Boston, M.A.

Andreani, Fr. 2007. Experiential marketing (sebuah pendekatan pemasaran). Jurnal Manajemen Pemasaran 2 (1) (April).

Baker, J., M. Levy, and D. Grewal. 1992. An Experimental Approach to Making Retail Store Environmental Decisions, Journal of Retailing 68 (4): 445-460.

Baron, R. A., and M. I. Bronfen. 1994. A whiff of reality: Empirical evidence concerning the effects of pleasant fragrances on work-related behavior. Journal of Applied Social Psychology 24 (13): 1179-1203.

Belk, R. W. 1975. Situational variables and consumer behavior. Journal of Consumer Research 2: 157-164.

Berman, B., and J. R. Evans. 2004. Retailing Management ( $\left(^{\text {th }}\right.$ ed.). New Jersey: Pearson Prentice Hall-Upper Saddle River.

Bolen, W. H. 1998. Contemporary Retailing ( $3^{\text {rd }}$ ed.). New Jersey: Pearson Prentice Hall-Upper Saddle River.

Bone, P. F., and P. S. Ellen. 1999. Scents in the marketplace: Explaining a fraction of olfaction. Journal of Retailing 75 (2): 243-262.

Bone, P. F., and S. Jantrania. 1992. Olfaction as a cue for product quality. Marketing Letters 3 (3): 289-296.

Chebat, J. C., and R. Michon. 2003. Impact of ambient odors on mall shoppers' emotions, cognition, and spending: A test of competitive causal theories. Journal of Business Research 56 (7): 529-539.

Davis, D. 2005. Business Research for Decision Making (6 ${ }^{\text {th }}$ ed.). Ohio: Thomson South Western.

Ellen, P. S., and P. F. Bone. 1998. Does it matter it smells? Olfactory stimuli as advertising executional cues. Journal of Advertising 27 (4): 29-39.

Epple, G., and Herz, R. S. 1999. The ascent of scent. Scientific American. 281(5), 42-43.

Fandos, C., and Flavian, C. 2006. Intrinsic and extrinsic quality attributes, loyalty, and buying intention: an analysis for PDO product. British Food Journal 108 (8): 646-662.

Fiore, A. M. 2002. Effects of experiential pleasure from a catalogue environment on approach responses toward fashion apparel. Journal of Fashion Marketing and Management 6 (2): 122-123.

Goldkuhl, L., and M. Styven. 2007. Sensing the scent of service success. European Journal of Marketing 41(11/12): 1297-1305.

Hair, J. F., W. C. Black, and B. J. Babin. 2010. Multivariate Data Analysis: A Global Perspective (7 $7^{\text {th }}$ ed.). New Jersey: Pearson Prentice Hall-Upper Saddle River.

Halloway, M. 1999. The ascent of scent. Scientific American 281 (5): 42-43.

Joreskog, K. G., and D. Sorbom. 1993. Latent variable scores and their uses. Retrieved from http:// wnw.ssicentral.com/lisrel/ column6.htm

Kahn, B. E., and D. R. Lehmann. 1991. Modeling choice among assortments. Journal of Retailing 67: 274299. 
Kertajaya, H., D. M. Yuswohady, and D. I. Bambi. 2003. Marketing in Venus. Jakarta: PT. Gramedia Pustaka Utama.

Knasko, S. 1989. Ambient odor and shopping behavior. Chemical Senses 14 (5): 179.

Kotler, P. 2003. Marketing Management (11 ${ }^{\text {th }}$ ed.). New Jersey: Pearson Prentice Hall-Upper Saddle River.

Kotler, P., and K. L. Kettler. 2009. Marketing Management (13 ${ }^{\text {th }}$ ed.). New Jersey: Pearson Prentice HallUpper Saddle River.

Levy, M., and B. A. Weitz. 2009. Retailing Management ( $7^{\text {th }}$ ed.). New York: McGraw-Hill.

Lindstorm, M. 2005. Brand Sense: Build Powerful Brands through Touch, Taste, Smell, Sight, and Sound. New York: Free Press.

Lipmann, J. 1990. Scents that encourage buying couldn't smell sweeter to stores. The Wall Street Journal (January 9): 5.

Loudon, D. L., and A. J. D. Bitta. 1993. Consumer Behavior: Concepts and Applications (4 $4^{\text {th }}$ ed.). New York: McGraw-Hill.

Maholtra, N. K. 2007. Marketing Research (5 $5^{\text {th }}$ ed.). New Jersey: Pearson Education, Inc.

Mehrabian, A., and J. A. Russell. 1974. An Approach to Environmental Psychology. Boston: MIT Press.

Morrin, M., and Ratneshwar, S. (2003). Does it make sense to use the scents to enhance brand memory?, Journal of Marketing Research, 40(1), 10-25.

Mitchell, D. J., B. E. Kahn, and S. C. Knasko. 1995. There's something in the air: effects of congruent or incongruent ambient odor on consumer decision making. Journal of Consumer Research 22 (2): 229238.

Parasuraman, A., V. A. Zeithaml, and L. L. Berry. 1985. A conceptual model of service quality and its implications for future research. Journal of Marketing 49: 41-50.

Pine, B. J. II, and J. H. Gilmore. 1999. The Experience Economy. Boston: Harvard Business School Press.

Schifferstein, H. N. J., and S. T. Blok. 2002. The signal function of thematically (in)congruent ambient scents in a retail environment. Chemical Senses 27 (6): 539-549.

Schiffman, L. G., and L. L. Kanuck. 2000. Consumer Behavior ( $7^{\text {th }}$ ed.). New Jersey: Pearson Prentice HallUpper Saddle River.

Schmitt, B. H. 1999. Experiential Marketing. New York: The Free Press.

Simamora, B. 2004. Panduan Riset Perilaku Konsumen. Jakarta: PT. Gramedia Pustaka Utama.

Soars, B. 2009. Driving sales through shoppers' sense of sound, sight, smell and touch. International Journal of Retail and Distribution Management 37 (3): 286-298.

Spangenberg, E. R., A. E. Crowley, and P. W. Henderson. 1996. Improving the store environment: do olfactory cues affect evaluations and behaviors? Journal of Marketing 60: 67-80.

Spence, C. 2002. The ICI report on the secrets of the senses. Retrieved from May, 13 2010, from: http:// ici.com/ICIPLC/ici-overview/sensism/pdfs/sense.pdf

Sullivan, M , and D. Adcock. 2002. Retail Marketing. Cornwall: Thomson.

Umar, H. 2005. Riset Pemasaran dan Perilaku Konsumen. Jakarta: PT. Gramedia Pustaka Utama.

Ward, P., B. J. Davies, and D. Kooijman. 2003. Ambient smell and the retail environment relating olfaction research to consumer behavior. Journal of Business and Management 9 (3): 289-302. 
GadjahMadaInternational Journal of Business -Jamuary-April,Vol. 13,No. 1,2011

Wells, W. D., and D. Prensky. 1996. Consumer Behavior. Toronto: John Wiley and Sons Inc.

Bataviase. 2010. Ritel bisa tembus angka Rp 115T. Retrieved September 09, 2010; from: http:/ / bataviase.co.id/ node/ 288412

Essential-Oil.Com. 2010. Pada kebijaksanaan 'otak bau' dan bagaimana mempengaruhi aroma tubuh kita. Retrieved from December 08, 2010; from: http:// essential-oil.com/id/aromatherapy-facts_on-the-wisdom-of-thesmell-brain-and-how\%20aromas-affect-our-body_647.html 